\title{
Oxygenated Terpenoids from a Formosan Soft Coral Sinularia gibberosa
}

\author{
Atallah F. Ahmed, ${ }^{\dagger, \downarrow}$ Yao-Haur Kuo, ${ }^{\S}$ Chang-Feng Dai, ${ }^{\perp}$ and Jyh-Horng Sheu ${ }^{*, \dagger}$ \\ Department of Marine Resources, National Sun Yat-Sen University, Kaohsiung 804, Taiwan, Republic of China, Department of \\ Pharmacognosy, Faculty of Pharmacy, Mansoura University, Mansoura 35516, Egypt, National Research Institute of Chinese \\ Medicine, Taipei 112, Taiwan, Republic of China, and Institute of Oceanography, National Taiwan University, Taipei 106, \\ Taiwan, Republic of China
}

Received April 4, 2005

Three new oxygenated sesquiterpenoids, gibberodione (1), peroxygibberol (2), and sinugibberodiol (3), along with sarcophytol L (4) were isolated from a Formosan soft coral, Sinularia gibberosa. The structures of the new metabolites were determined on the basis of extensive spectroscopic analyses and by comparison of NMR data with those of related metabolites. Metabolites $\mathbf{2}$ and $\mathbf{4}$ were found to exhibit moderate cytotoxicity toward a human liver carcinoma cell line.

During the course of our screening for bioactive metabolites from marine organisms,${ }^{1-5}$ several bioactive steroids have been isolated and identified from the soft coral Sinularia gibberosa Tixier-Durivault growing in Taiwanese waters. ${ }^{6}$ Further investigation on the chemical constituents of the dichloromethane extract of the Formosan soft coral $S$. gibberosa has afforded three new oxygenated sesquiterpenoids, which were identified as $(1 S, 10 S, 6 E)-4,5$-secoguai-6-en-4,5-dione (gibberodione, 1), (1 $\left.S^{*}, 4 R^{*}, 7 S^{*}, 10 S^{*}\right)$ 4-hydroxyguai-5-en-1,7-endoperoxide (peroxygibberol, 2), and $\left(3 S^{*}, 7 S^{*}, 9 S^{*}\right)-3,9$-dihydroxygermacra-4(15),10(14),11(12)-triene (sinugibberodiol, 3), along with the known diterpenoid sarcophytol L (4). The structures of the new metabolites were determined on the basis of extensive NMR spectroscopic analyses, by comparison of spectroscopic data with those of related metabolites, and by chemical reaction. The relative configuration of $\mathbf{1}-\mathbf{3}$ was established by careful NOESY spectroscopic analyses. The cytotoxic activity of $\mathbf{1}, \mathbf{2}$, and $\mathbf{4}$ against the growth of Hepa59T/VGH (human liver carcinoma) and KB (human oral epidermoid carcinoma) was also evaluated.

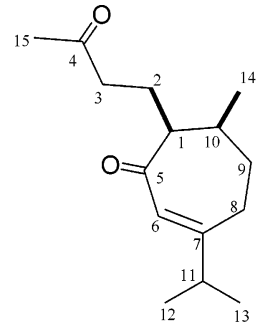

1

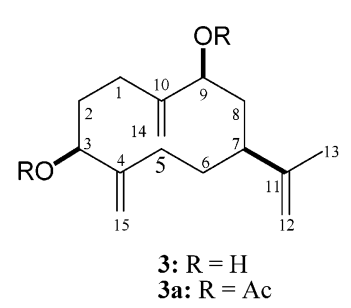

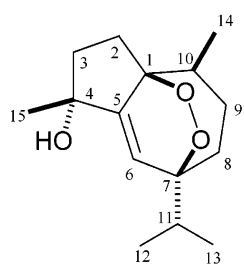

2

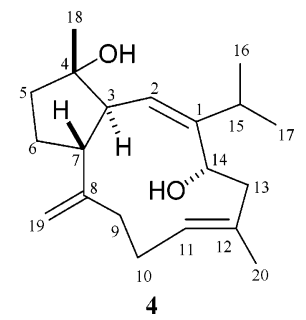

* To whom correspondence should be addressed. Tel: 886-7-5252000, ext. 5030. Fax: 886-7-5255020. E-mail: sheu@mail.nsysu.edu.tw.

National Sun Yat-Sen University.

* Mansoura University.

$\S$ National Research Institute of Chinese Medicine.

${ }^{\perp}$ National Taiwan University.

\section{Results and Discussion}

The organism $S$. gibberosa was exhaustively extracted with EtOH. The concentrated crude alcoholic extract was successively partitioned with $n$-hexane and dichloromethane to afford the $n$-hexane and dichloromethane fractions. Chromatographic fractionation of the dichloromethane fraction, using normal-phase MPLC and HPLC, yielded metabolites 1-4 (see Experimental Section).

Gibberodione (1) was obtained as a colorless oil. Its HREIMS $\left(\mathrm{m} / z\right.$ 236.1781, $\left.[\mathrm{M}]^{+}\right)$and NMR data (Table 1) suggested the molecular formula $\mathrm{C}_{15} \mathrm{H}_{24} \mathrm{O}_{2}$, implying four degrees of unsaturation. The IR spectrum revealed the presence of a carbonyl functionality $\left(v_{\max } 1715 \mathrm{~cm}^{-1}\right)$ and the absence of any hydroxy groups. The ${ }^{13} \mathrm{C}$ NMR spectrum of 1 , measured in pyridine- $d_{5}$, displayed 15 carbon signals assigned to four methyl, four $\mathrm{sp}^{3}$ methylene, three $\mathrm{sp}^{3}$ methine, one $\mathrm{sp}^{2}$ methine, and three $\mathrm{sp}^{2}$ quaternary carbons. The carbon signals at $\delta 128.3(\mathrm{CH}), 169.6(\mathrm{C})$, and 202.6 (C) were assigned to an $\alpha, \beta$-unsaturated ketone, which was further supported by the appearance of a downfield shifted olefinic proton resonating at $\delta 6.04(1 \mathrm{H}$, br $\mathrm{s}$ ) in the ${ }^{1} \mathrm{H}$ NMR spectrum of $\mathbf{1}$. One additional ketone was also revealed from the carbon signal appearing at $\delta$ 208.0 (C). Metabolite 1 was thus established as a monocyclic sesquiterpenoid. The proton signals displayed in the ${ }^{1} \mathrm{H} \mathrm{NMR}$ at $\delta 0.75,0.91$, and 0.92 (each $\left.3 \mathrm{H}, \mathrm{d}, J=6.6 \mathrm{~Hz}\right)$ were assigned as three secondary methyl groups, in which two methyls were found to be correlated in the ${ }^{1} \mathrm{H}-{ }^{1} \mathrm{H}$ COSY spectrum with the allylic methine appearing at $\delta$ $2.22(1 \mathrm{H}, \mathrm{t}, J=6.6 \mathrm{~Hz})$, implying the presence of an isopropyl group. Moreover, a 3-oxobutyl group was also deduced as a side chain from the ${ }^{1} \mathrm{H} /{ }^{13} \mathrm{C}$ long-range correlations observed from both of the acetyl protons at $\delta 2.03$ $(3 \mathrm{H}, \mathrm{s})$ and the four protons of two methylenes $(\delta 1.69,2.34$, 2.37 , and 2.51 , each $1 \mathrm{H}, \mathrm{m}$ ) to the carbonyl carbon at $\delta$ 208.0. Furthermore, the fragment ion peaks appearing in the EIMS spectrum at $m / z 193\left[\mathrm{M}-\mathrm{C}_{3} \mathrm{H}_{7}\right]^{+}$and $165[\mathrm{M}-$ $\left.\mathrm{C}_{4} \mathrm{H}_{7} \mathrm{O}\right]^{+}$were considered to arise from the elimination of an isopropyl and an oxobutyl moiety, respectively, from the molecular ion of $\mathbf{1}$. The above observations together with ${ }^{1} \mathrm{H}-{ }^{1} \mathrm{H}$ COSY and HMBC data (Table 1 and Figure 1) indicated that compound $\mathbf{1}$ should possess a conjugated cycloheptenone ring substituted with an isopropyl, a 3-oxobutyl, and a secondary methyl. These substituents were found to be linked to the cycloheptenone ring at C-7, C-1, and $\mathrm{C}-10$, respectively, as interpreted from the correlations found in the ${ }^{1} \mathrm{H}-{ }^{1} \mathrm{H}$ COSY and HMBC spectra of $\mathbf{1}$. Comparison of the ${ }^{13} \mathrm{C} \mathrm{NMR}$ data of 1 measured in $\mathrm{CDCl}_{3}$ 
Table 1. ${ }^{1} \mathrm{H}(300 \mathrm{MHz}),{ }^{13} \mathrm{C}(75 \mathrm{MHz})$, and $2 \mathrm{D}$ NMR Data ${ }^{a}$ for $\mathbf{1}$

\begin{tabular}{|c|c|c|c|c|}
\hline atom & $\delta_{\mathrm{C}}$ & $\delta_{\mathrm{H}}$ & $\mathrm{COSY}^{d}$ & $\mathrm{HMBC}^{e}$ \\
\hline 1 & $53.0(\mathrm{CH})^{b}$ & $2.90 \mathrm{ddd}(9.6,5.2,5.2)^{c}$ & $\mathrm{H}_{2}-2, \mathrm{H}-10$ & C-2, C-3, C-5, C-9, C-10, C-14 \\
\hline 2 & $22.8\left(\mathrm{CH}_{2}\right)$ & $\begin{array}{l}2.34 \mathrm{~m} \\
1.69 \mathrm{~m}\end{array}$ & $\mathrm{H}-1, \mathrm{H}_{2}-3$ & C-1, C-3, C-4, C-5, C-10 \\
\hline 3 & $41.9\left(\mathrm{CH}_{2}\right)$ & $\begin{array}{l}2.37 \mathrm{~m} \\
2.51 \mathrm{~m}\end{array}$ & $\mathrm{H}_{2}-2$ & C-1, C-2, C-4 \\
\hline $\begin{array}{l}4 \\
5\end{array}$ & $\begin{array}{l}208.0(\mathrm{C}) \\
202.6(\mathrm{C})\end{array}$ & & & \\
\hline 6 & $128.3(\mathrm{CH})$ & $6.04 \mathrm{br} \mathrm{s}$ & $\mathrm{H}_{2}-8, \mathrm{H}-11$ & C-1, C-7, C-8, C-11 \\
\hline $\begin{array}{l}7 \\
8\end{array}$ & $\begin{array}{l}169.6(\mathrm{C}) \\
29.6\left(\mathrm{CH}_{2}\right)\end{array}$ & $\begin{array}{l}2.16 \mathrm{dd}(17.5,6.5), \alpha \\
2.33 \mathrm{~m}, \beta\end{array}$ & $\mathrm{H}-6, \mathrm{H}_{2}-9$ & C-6, C-7, C-9, C-10, C-11 \\
\hline 9 & $36.6\left(\mathrm{CH}_{2}\right)$ & $\begin{array}{l}1.99 \mathrm{~m}, \alpha \\
0.93 \mathrm{~m}, \beta\end{array}$ & $\mathrm{H}_{2}-8, \mathrm{H}-10$ & C-1, C-7, C-8, C-10 \\
\hline 10 & $33.5(\mathrm{CH})$ & $1.95 \mathrm{~m}$ & $\mathrm{H}-1, \mathrm{H}_{2}-9, \mathrm{H}_{3}-14$ & C-2, C-5, C-8, C-9, C-14 \\
\hline 11 & $38.0(\mathrm{CH})$ & $2.22 \mathrm{t}(6.6)$ & $\mathrm{H}-6, \mathrm{H}_{3}-12, \mathrm{H}_{3}-13$ & C- 6, C-7, C-8, C-12, C-13 \\
\hline 12 & $20.5\left(\mathrm{CH}_{3}\right)$ & $0.913 \mathrm{H}, \mathrm{d}(6.6)$ & H-11 & C-7, C-11, C-13 \\
\hline 13 & $20.9\left(\mathrm{CH}_{3}\right)$ & $0.923 \mathrm{H}, \mathrm{d}(6.6)$ & H-11 & $\mathrm{C}-7, \mathrm{C}-11, \mathrm{C}-12$ \\
\hline 14 & $16.3\left(\mathrm{CH}_{3}\right)$ & $0.753 \mathrm{H}, \mathrm{d}(6.6)$ & H-10 & C-1, C-9, C-10 \\
\hline 15 & $29.6\left(\mathrm{CH}_{3}\right)$ & $2.033 \mathrm{H}, \mathrm{s}$ & & C-3, C-4 \\
\hline
\end{tabular}

${ }^{a}$ Spectra recorded in $\mathrm{C}_{5} \mathrm{D}_{5} \mathrm{~N} .{ }^{b}$ Attached protons were determined by DEPT experiments. ${ }^{c}$ The $J$ values are in $\mathrm{Hz}$ in parentheses. ${ }^{d}$ Correlations $\mathrm{H} \rightarrow \mathrm{H}$. ${ }^{e}$ Correlations $\mathrm{H} \rightarrow \mathrm{C}$.

(see Experimental Section) with those of 4,5-seco-guaiane $\mathbf{5}$ isolated from a liverwort ${ }^{7}$ revealed that $\mathbf{1}$ has the same carbon skeleton as that of $\mathbf{5}$ except that the hemiketal and $\mathrm{sp}^{3}$ oxygenated quaternary carbons ( $\delta 98.6$ and 91.8, respectively $)^{7}$ of the tetrahydrofuran ring in $\mathbf{5}$ were replaced by a carbonyl $(\delta 206.0)$ and a methine ( $\delta 52.8)$ carbon in 1. On the basis of the above findings, the planar structure of gibberodione (1) was thus established as 4,5secoguai-6-ene-4,5-dione.
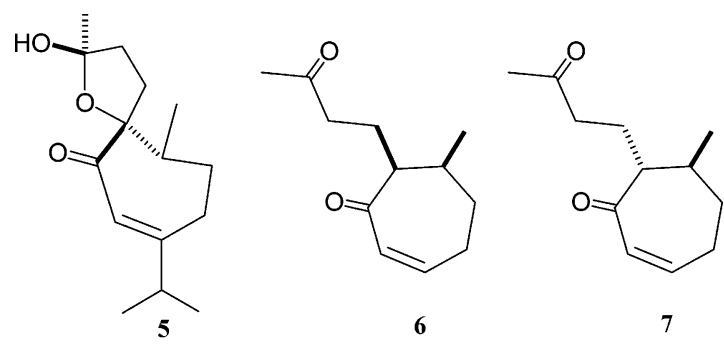

$$
5
$$

6

7<smiles>CC(C)[C@@]12C=C3[C@@](C)(O)CC[C@]3(OO1)[C@H](C)CC2</smiles><smiles>CC(C)[C@@]12C=C3[C@@H](C)CCC3(OO1)[C@H](C)CC2</smiles>

8

9

The relative configuration of $\mathbf{1}$ was deduced from NOE interactions (Figure 2) observed in the NOESY spectrum and by comparison of NMR spectroscopic data with those of related compounds. The NOE correlations observed between $\mathrm{H}-1$ and $\mathrm{H}-10$ but not between $\mathrm{H}-1$ and $\mathrm{H}_{3}-14$ reflected the cis orientation of $\mathrm{H}-10$ and $\mathrm{H}-1$. Furthermore, the NOE interactions found between the olefinic proton H-6 and the protons of the isopropyl methyl groups assigned the $Z$-configuration of the 6,7-double bond. By further inspection of NMR data of 2-cycloheptenone-derived compounds, it was found that clavularin A (6), with a $1 S, 10 S$ configuration, showed marked upfield shifts at the secondary methyl $\left(\delta_{\mathrm{H}} 0.83\right.$ and $\delta_{\mathrm{C}} 15.7$ in $\left.\mathrm{CDCl}_{3}\right)$ relative to those of a $1 R, 10 S$-configured isomer, clavularin $\mathrm{B}(\mathbf{7})\left(\delta_{\mathrm{H}} 1.09\right.$ and $\delta_{\mathrm{C}} 19.9$ in $\left.\mathrm{CDCl}_{3}\right)^{8,9}$ Therefore, the chemical shifts of $\mathrm{H}_{3}-14$ in $1\left(\delta_{\mathrm{H}} 0.79\right.$ and $\delta_{\mathrm{C}} 16.2$ in $\left.\mathrm{CDCl}_{3}\right)$ could indicate the same relative configuration in $\mathbf{1}$ as that of $\mathbf{6}$. The same sign of optical rotations of $\mathbf{1}\left([\alpha]_{\mathrm{D}}+20.8^{\circ}, \mathrm{CHCl}_{3}\right)$ and $\mathbf{6}$
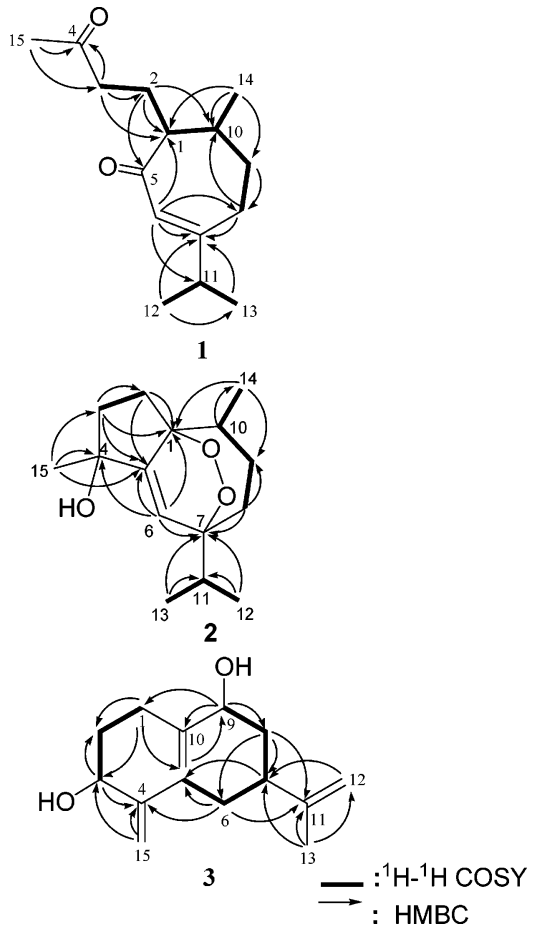

Figure 1. ${ }^{1} \mathrm{H}-1 \mathrm{H}$ COSY and $\mathrm{HMBC}$ correlations for 1-3.

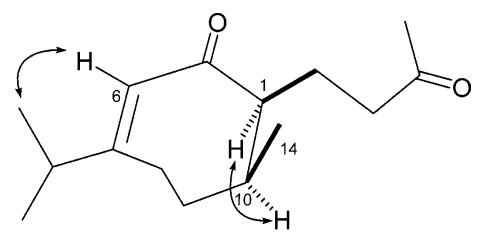

1

NOE $\longleftrightarrow$

Figure 2. Key NOESY correlations of $\mathbf{1}$.

$\left([\alpha]_{\mathrm{D}}+59.2^{\circ}, \mathrm{CHCl}_{3}\right)$ suggests that $\mathbf{1}$ should have the same $1 S, 10 S$ absolute configuration as that of $\mathbf{6}$. Therefore, the structure of gibberodione was assigned as $(1 S, 10 S, 6 E)-4,5$ secoguai-6-en-4,5-dione.

The new metabolite peroxygibberol (2) was also obtained as a colorless oil. The molecular formula of $\mathbf{2}$ was established as $\mathrm{C}_{15} \mathrm{H}_{24} \mathrm{O}_{3}$ by HRESIMS $\left(\mathrm{m} / z\right.$ 275.1621, $\left.[\mathrm{M}+\mathrm{Na}]^{+}\right)$ 
Table 2. ${ }^{1} \mathrm{H}$ and ${ }^{13} \mathrm{C}$ NMR Chemical Shifts for Compounds $\mathbf{2}, \mathbf{8},{ }^{11}$ and $\mathbf{9}^{12}$

\begin{tabular}{|c|c|c|c|c|}
\hline \multirow[b]{2}{*}{ atom } & \multicolumn{2}{|r|}{$\mathbf{2}^{a}$} & \multirow{2}{*}{$\frac{\mathbf{8}^{b 11}}{\delta_{\mathrm{H}}}$} & \multirow{2}{*}{$\frac{\mathbf{9}^{c 12}}{\delta_{\mathrm{C}}}$} \\
\hline & $\delta_{\mathrm{C}}$ & $\delta_{\mathrm{H}}$ & & \\
\hline 1 & $89.3(\mathrm{C})^{d}$ & & & $91.4(\mathrm{C})$ \\
\hline \multirow[t]{2}{*}{2} & $34.9\left(\mathrm{CH}_{2}\right)$ & $2.07 \mathrm{~m}, \alpha$ & $2.27 \mathrm{~m}$ & $36.4\left(\mathrm{CH}_{2}\right)$ \\
\hline & & $1.87 \mathrm{~m}, \beta$ & $1.80 \mathrm{~m}$ & \\
\hline \multirow[t]{2}{*}{3} & $39.0\left(\mathrm{CH}_{2}\right)$ & $1.83 \mathrm{~m}, \alpha$ & $1.80 \mathrm{~m}$ & $31.7\left(\mathrm{CH}_{2}\right)$ \\
\hline & & $1.83 \mathrm{~m}, \beta$ & $1.80 \mathrm{~m}$ & \\
\hline 4 & $78.5(\mathrm{C})$ & & & $36.8(\mathrm{CH})$ \\
\hline 5 & $152.4(\mathrm{C})$ & & & $150.3(\mathrm{C})$ \\
\hline 6 & $120.0(\mathrm{CH})$ & $5.99 \mathrm{~s}$ & $6.11 \mathrm{~s}$ & $122.8(\mathrm{CH})$ \\
\hline 7 & $83.2(\mathrm{C})$ & & & $83.3(\mathrm{C})$ \\
\hline \multirow[t]{2}{*}{8} & $30.9\left(\mathrm{CH}_{2}\right)$ & $1.89 \mathrm{~m}, \alpha$ & $1.75 \mathrm{t}(6.0)$ & $31.0\left(\mathrm{CH}_{2}\right)$ \\
\hline & & 1.67 ddd $(14.4,4.5,4.5),{ }^{e} \beta$ & $1.75 \mathrm{t}(6.0)$ & \\
\hline \multirow[t]{2}{*}{9} & $28.2\left(\mathrm{CH}_{2}\right)$ & $1.43 \mathrm{~m}, \alpha$ & $1.23 \mathrm{~m}$ & $30.3\left(\mathrm{CH}_{2}\right)$ \\
\hline & & $1.49 \mathrm{~m}, \beta$ & $2.19 \mathrm{~m}$ & \\
\hline 10 & $39.1(\mathrm{CH})$ & $1.96 \mathrm{~m}$ & $2.11 \mathrm{~m}$ & $39.1(\mathrm{CH})$ \\
\hline 11 & $35.6(\mathrm{CH})$ & $1.87 \mathrm{~m}$ & $1.86 \mathrm{qq}(7.0,7.0)$ & $35.4(\mathrm{CH})$ \\
\hline 12 & $17.0\left(\mathrm{CH}_{3}\right)$ & $0.983 \mathrm{H}, \mathrm{d}(6.9)$ & $0.993 \mathrm{H}, \mathrm{d}(7.0)$ & $16.8\left(\mathrm{CH}_{3}\right)$ \\
\hline 13 & $17.1\left(\mathrm{CH}_{3}\right)$ & $0.973 \mathrm{H}, \mathrm{d}(6.9)$ & $0.963 \mathrm{H}, \mathrm{d}(7.0)$ & $17.0\left(\mathrm{CH}_{3}\right)$ \\
\hline 14 & $13.7\left(\mathrm{CH}_{3}\right)$ & $1.083 \mathrm{H}, \mathrm{d}(6.9)$ & $1.023 \mathrm{H}, \mathrm{d}(7.0)$ & $18.0\left(\mathrm{CH}_{3}\right)$ \\
\hline 15 & $25.2\left(\mathrm{CH}_{3}\right)$ & $1.533 \mathrm{H}, \mathrm{s}$ & $1.543 \mathrm{H}, \mathrm{s}$ & $19.1\left(\mathrm{CH}_{3}\right)$ \\
\hline
\end{tabular}

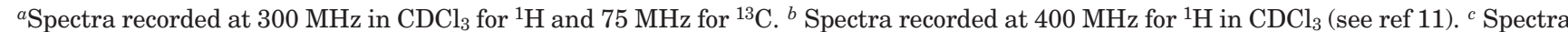
recorded at $125 \mathrm{MHz}$ for ${ }^{13} \mathrm{C}$ in $\mathrm{CDCl}_{3}$ (see ref 12). ${ }^{d}$ Attached protons were determined by DEPT experiments. ${ }^{e}$ The $J$ values are in Hz in parentheses.

and NMR spectroscopic data (Table 2). Thus, the structure of 2 possesses four degrees of unsaturation. The presence of the hydroxy functionality in $\mathbf{2}$ was revealed from the IR absorption band at $v_{\max } 3598 \mathrm{~cm}^{-1}$. The ${ }^{13} \mathrm{C}$ NMR spectrum of 2 showed signals of 15 carbons, including those of four methyls ( $\delta 25.2,17.0,17.1$, and 13.7) and three quaternary $\mathrm{sp}^{3}$ oxycarbons ( $\delta 89.3,83.2$, and 78.5$)$, as assigned by the DEPT spectrum, suggesting the oxygenated sesquiterpenoid nature of $\mathbf{2}$ (Table 2). Furthermore, the carbon signals at $\delta 120.0(\mathrm{CH})$ and $152.4(\mathrm{C})$ indicated the presence of one trisubstituted double bond. Thus, the tricyclic structure of 2 was revealed. From the ${ }^{1} \mathrm{H}-{ }^{1} \mathrm{H}$ COSY and HMBC correlations, the guaiane-type skeleton of $\mathbf{2}$ was established (Figure 1). The hydroxy group should be positioned at a methyl-bearing carbon $\mathrm{C}-4$, as designated by the HMBC correlations observed from the tertiary methyl $\left(\delta_{\mathrm{H}} 1.53\right)$ to the quaternary carbons at $\delta 78.5(\mathrm{C}-4)$ and $152.4(\mathrm{C}-5)$. Therefore, the two additional oxygen atoms should be used to form an endoperoxide bridge in the cycloheptene moiety of the molecule. This was further supported by the intense ion peak in the mass spectrum appearing at $\mathrm{m} / \mathrm{z} 220[\mathrm{M}-$ $\left.\mathrm{O}_{2}\right]^{+}$. The ${ }^{1} \mathrm{H} /{ }^{13} \mathrm{C}$ long-range correlations found from the olefinic proton $\mathrm{H}-6(\delta 5.99, \mathrm{~s})$ to $\mathrm{C}-1(\delta 89.3, \mathrm{C})$ and $\mathrm{C}-7(\delta$ $83.2, \mathrm{C})$ further established the 1,7-endoperoxide linkage. It was found that the ${ }^{1} \mathrm{H} \mathrm{NMR}$ data of $\left(1 S^{*}, 4 R^{*}, 7 S^{*}, 10 R^{*}\right)$ 4-hydroxyguai-5-en-1,7-endoperoxide (8), ${ }^{11}$ isolated from Liabum floribundum, were highly similar to those of $\mathbf{2}$ (Table 2), except for the significant downfield shift observed at one of the $\mathrm{H}_{2}-9$ protons $\left(\Delta \delta_{\mathrm{H}}+0.70 \mathrm{ppm}\right)$ relative to that of $\mathbf{2}$. These findings suggested that $\mathbf{2}$ might be the C-10 epimer of $\mathbf{8}$. Due to the lack of ${ }^{13} \mathrm{C}$ data for $\mathbf{8}$, we further compared the ${ }^{13} \mathrm{C}$ NMR spectroscopic data of $\mathbf{2}$ with those of $\mathbf{9}, 12$ a compound with a structure closely related to that of $\mathbf{2}$ and $\mathbf{8}$. We observed that $\mathbf{9}$ also exhibited downfield shifts at C-1, C-9, and C-14 $\left(\Delta \delta_{\mathrm{C}}+2.1,+2.1\right.$, and $+4.3 \mathrm{ppm}$, respectively) relative to those of $\mathbf{2}$, and thus further supported our assumption that the methyl group attached at C-10 should be $\beta$-oriented. The significant upfield shifted C-14 in 2 can be explained by the strong $\gamma$-effect ${ }^{13}$ arising from the steric compression of a gauche interaction between 10- $\mathrm{CH}_{3}$ and both the $\mathrm{C}_{1}-\mathrm{C}_{2}$ and $\mathrm{C}_{1}-\mathrm{O}$ single bonds. The above observations together with the NOE correlations (Figure 3) observed in the NOESY spectrum supported the

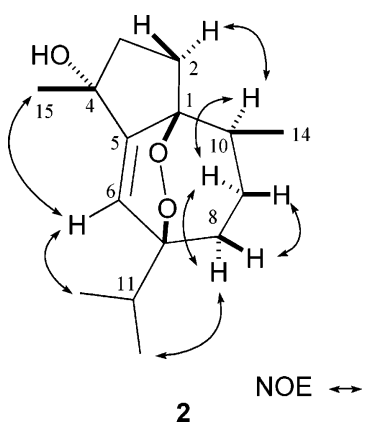

Figure 3. Observed NOESY correlations of 2 .

relative structure of peroxygibberol (2) as $\left(1 S^{*}, 4 R^{*}, 7 S^{*},-\right.$ $10 S^{*}$ )-4-hydroxyguai-5-en-1,7-endoperoxide.

The sesquiterpenoid metabolite sinugibberodiol (3) was also obtained as a colorless oil. Its HRFABMS spectroscopic data $(\mathrm{m} / \mathrm{z}$ 237.1853) suggested the molecular formula $\mathrm{C}_{15} \mathrm{H}_{24} \mathrm{O}_{2}$, requiring 4 degrees of unsaturation. Two hydroxy groups were found from the IR $\left(\nu_{\max } 3397 \mathrm{~cm}^{-1}\right)$ and FABMS $\left(m / z 219\left[\mathrm{M}-\mathrm{H}_{2} \mathrm{O}+\mathrm{H}\right]^{+}\right.$and $201\left[\mathrm{M}-2 \mathrm{H}_{2} \mathrm{O}+\right.$ $\mathrm{H}]^{+}$) data. The ${ }^{1} \mathrm{H}$ NMR data of 3 (Table 3 ) revealed the presence of three exomethylenes $(\delta 5.19,5.11,4.70,4.68$, each $1 \mathrm{H}, \mathrm{s}$ and $5.06,2 \mathrm{H}, \mathrm{s})$, one olefinic methyl $(\delta 1.69$, $3 \mathrm{H}, \mathrm{s})$, and two hydroxy-bearing methines $(\delta 4.21,1 \mathrm{H}, \mathrm{t}, J$ $=6.6 \mathrm{~Hz}$ and $\delta 4.00,1 \mathrm{H}, \mathrm{dd}, J=11.4,3.0 \mathrm{~Hz})$. The ${ }^{13} \mathrm{C}$ NMR spectrum of 3 displayed 15 carbon signals, which indicated the presence of three 1,1-disubstituted double bonds $(\delta 150.2,149.7,148.0$, each qC and 114.7, 114.0, 110.2 , each $\left.\mathrm{CH}_{2}\right)$, one methyl $(\delta 19.1)$, two oxymethines $(\delta$ 76.7 and 74.6), and five methylene and one nonoxygenated methine (Table 3). The above observations together with the ${ }^{1} \mathrm{H}-{ }^{1} \mathrm{H}$ COSY and HMBC correlations (Figure 1) established the planar structure of $\mathbf{3}$ and revealed that $\mathbf{3}$ is a germacrane-based sesquiterpene. ${ }^{14}$

The relative configurations at C-3, C-7, and C-9 were determined by careful and detailed investigation of NOE interactions (Figure 4) displayed in the NOESY spectra of 3 and its diacetate 3a. Assuming the $\alpha$-orientation of $\mathrm{H}-7,{ }^{15}$ the NOE correlations observed between the oxymethine protons H-9 and H-7 with $\mathrm{H}-8 \alpha$ indicated the $\beta$-orientation of the 9-OH. Since no other useful NOE correlations that could be used to establish the relative configuration at C-3 
Table 3. ${ }^{1} \mathrm{H}$ and ${ }^{13} \mathrm{C}$ NMR Chemical Shifts for $\mathbf{3}$ and $\mathbf{3 a}$

\begin{tabular}{|c|c|c|c|c|}
\hline \multirow[b]{2}{*}{ atom } & \multicolumn{2}{|r|}{$\mathbf{3}^{a}$} & \multicolumn{2}{|r|}{$\mathbf{3 a}^{b}$} \\
\hline & $\delta_{\mathrm{C}}$ & $\delta_{\mathrm{H}}$ & $\delta_{\mathrm{C}}$ & $\delta_{\mathrm{H}}$ \\
\hline 1 & $24.3\left(\mathrm{CH}_{2}\right)^{c}$ & $\begin{array}{l}2.10 \mathrm{~m} \\
2.30 \mathrm{dd}(18.0,9.0)^{d}\end{array}$ & $24.7\left(\mathrm{CH}_{2}\right)$ & $\begin{array}{l}2.09 \mathrm{~m} \\
2.30 \mathrm{~m}\end{array}$ \\
\hline 2 & $32.7\left(\mathrm{CH}_{2}\right)$ & $\begin{array}{l}2.08 \mathrm{~m}, \alpha \\
2.08 \mathrm{~m}, \beta\end{array}$ & $29.5\left(\mathrm{CH}_{2}\right)$ & $\begin{array}{l}2.11 \mathrm{~m} \\
2.11 \mathrm{~m}\end{array}$ \\
\hline $\begin{array}{l}3 \\
4\end{array}$ & $\begin{array}{l}74.6(\mathrm{CH}) \\
149.7(\mathrm{C})\end{array}$ & $4.21 \mathrm{t}(6.6)$ & $\begin{array}{l}76.0(\mathrm{CH}) \\
144.9(\mathrm{C})\end{array}$ & $5.40 \mathrm{dd}(8.5,5.0)$ \\
\hline 5 & $30.6\left(\mathrm{CH}_{2}\right)$ & $\begin{array}{l}1.55 \mathrm{~m}, \alpha \\
2.34 \text { ddd }(14.8,5.5,5.5), \beta\end{array}$ & $30.4\left(\mathrm{CH}_{2}\right)$ & $\begin{array}{l}1.70 \text { ddd }(14.5,7.5,4.5) \\
2.37 \text { ddd }(14.5,7.5,4.5)\end{array}$ \\
\hline 6 & $32.1\left(\mathrm{CH}_{2}\right)$ & $\begin{array}{l}1.59 \mathrm{~m}, \alpha \\
1.64 \mathrm{~m}, \beta\end{array}$ & $31.1\left(\mathrm{CH}_{2}\right)$ & $\begin{array}{l}1.56 \mathrm{~m} \\
1.77 \mathrm{~m}\end{array}$ \\
\hline 7 & $41.2(\mathrm{CH})$ & $2.11 \mathrm{~m}$ & $40.5(\mathrm{CH})$ & $2.22 \mathrm{qq}(4.0)$ \\
\hline 8 & $37.1\left(\mathrm{CH}_{2}\right)$ & $\begin{array}{l}1.64 \mathrm{~m}, \alpha \\
1.85 \text { ddd }(14.0,11.4,3.0), \beta\end{array}$ & $34.3\left(\mathrm{CH}_{2}\right)$ & $\begin{array}{l}1.67 \mathrm{~m} \\
1.90 \mathrm{ddd}(13.5,12.0,4.0)\end{array}$ \\
\hline $\begin{array}{l}9 \\
10 \\
11\end{array}$ & $\begin{array}{c}76.7(\mathrm{CH}) \\
150.2(\mathrm{C})\end{array}$ & $4.00 \mathrm{dd}(11.4,3.0)$ & $\begin{array}{c}78.4(\mathrm{CH}) \\
145.0(\mathrm{C})\end{array}$ & $5.09 \mathrm{dd}(12.0,4.0)$ \\
\hline $\begin{array}{l}11 \\
12\end{array}$ & $110.2\left(\mathrm{CH}_{2}\right)$ & $\begin{array}{l}4.68 \mathrm{~s} \\
4.70 \mathrm{~s}\end{array}$ & $110.6\left(\mathrm{CH}_{2}\right)$ & $\begin{array}{l}4.72 \mathrm{~s} \\
4.73 \mathrm{~s}\end{array}$ \\
\hline 13 & $19.1\left(\mathrm{CH}_{3}\right)$ & $1.693 \mathrm{H}, \mathrm{s}$ & $19.3\left(\mathrm{CH}_{3}\right)$ & $1.693 \mathrm{H}, \mathrm{s}$ \\
\hline 14 & $114.7\left(\mathrm{CH}_{2}\right)$ & $\begin{array}{l}5.06 \mathrm{~s} \\
5.11 \mathrm{~s}\end{array}$ & $117.0\left(\mathrm{CH}_{2}\right)$ & $\begin{array}{l}5.18 \mathrm{~s} \\
5.21 \mathrm{~s}\end{array}$ \\
\hline 15 & $114.0\left(\mathrm{CH}_{2}\right)$ & $\begin{array}{l}5.06 \mathrm{~s} \\
5.19 \mathrm{~s}\end{array}$ & $116.8\left(\mathrm{CH}_{2}\right)$ & $\begin{array}{l}5.16 \mathrm{~s} \\
5.26 \mathrm{~s}\end{array}$ \\
\hline 3-Ac & & & $\begin{array}{l}21.4\left(\mathrm{CH}_{3}\right) \\
169.9(\mathrm{C})\end{array}$ & $2.003 \mathrm{H}, \mathrm{s}$ \\
\hline 9-Ac & & & $\begin{array}{l}21.4\left(\mathrm{CH}_{3}\right) \\
170.4(\mathrm{C})\end{array}$ & $2.053 \mathrm{H}, \mathrm{s}$ \\
\hline
\end{tabular}

${ }^{a}$ Spectra recorded at $300 \mathrm{MHz}$ in $\mathrm{CDCl}_{3}$ for ${ }^{1} \mathrm{H}$ and $75 \mathrm{MHz}$ for ${ }^{13} \mathrm{C}$. ${ }^{b}$ Spectra recorded at $500 \mathrm{MHz}$ in $\mathrm{CDCl}_{3}$ for ${ }^{1} \mathrm{H}$ and $125 \mathrm{MHz}$ for ${ }^{13} \mathrm{C}$. ${ }^{c}$ Attached protons were determined by DEPT experiments. ${ }^{d}$ The $J$ values are in $\mathrm{Hz}$ in parentheses.

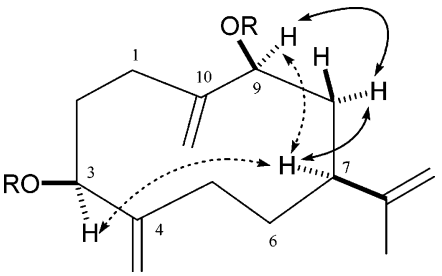

Figure 4. Observed NOESY correlations for $\mathbf{3}, \mathrm{R}=\mathrm{H}$ (solid arrows), and $\mathbf{3 a}, \mathrm{R}=\mathrm{Ac}$ (dashed and solid arrows).

were found, the diacetate $\mathbf{3 a}$ was prepared for further NOE analysis. It was found that both $\mathrm{H}-9$ and $\mathrm{H}-3$ of $\mathbf{3 a}$ exhibited NOE correlations with H-7. Thus, H-3, either in $\mathbf{3}$ or $\mathbf{3 a}$, was found to be positioned on the $\alpha$ face. Therefore, the relative structure of sinugibberodiol (3) was established as $\left(3 S^{*}, 7 S^{*}, 9 S^{*}\right)-3,9$-dihydroxygermacra-4(15),10(14),11(12)-triene.

It should be noted that the structure of $\mathbf{3 a}$ is the same as that of chrysanthediacetate $B$, which was isolated previously from Chrysanthemum morifolium. ${ }^{15}$ However, the optical rotation of $\mathbf{3 a}\left([\alpha]_{\mathrm{D}}-36.3^{\circ}, \mathrm{MeOH}\right)$ has the opposite sign relative to that of chrysanthediacetate $\mathrm{B}\left([\alpha]_{\mathrm{D}}+45.53^{\circ}\right.$, $\mathrm{MeOH})^{15}$ and thus must be the enantiomer. Also, it was reported that a similar sesquiterpene, eleganodiol, has been purified by acetylation of a crude sesquiterpene-containing fraction obtained from Gonospermum elegans. ${ }^{16}$ The afforded diacetyleleganodiol possesses ${ }^{1} \mathrm{H}$ and ${ }^{13} \mathrm{C}$ NMR data nearly identical to those of $\mathbf{3 a}$ and chrysanthediacetate $\mathrm{B},{ }^{15}$ but with an optical activity $\left([\alpha]_{\mathrm{D}}+9^{\circ}, \mathrm{CHCl}_{3}\right)$ deviating markedly in magnitude, suggesting the possibility that it might be a mixture of $\mathbf{3 a}$ and chrysanthediacetate $\mathrm{B}$.

The sesquiterpene metabolites $(\mathbf{1}, \mathbf{2}$, and $\mathbf{4})$ were evaluated for their in vitro cytotoxic activity against Hepa59T/ VGH and KB cancer cell lines. The results showed that 2 and 4 exhibited moderate cytotoxicity against the growth of the Hepa59T/VGH cell line ( $\mathrm{ED}_{50}$ 's 8.2 and $12.6 \mu \mathrm{g} / \mathrm{mL}$, respectively), while they were not cytotoxic against $\mathrm{KB}$ cell lines. Gibberodione $\mathbf{1}$ was found to be inactive $\left(\mathrm{ED}_{50}>30\right.$ $\mu \mathrm{g} / \mathrm{mL}$ ) against both cancer cell lines.

\section{Experimental Section}

General Experimental Procedures. Optical rotations were measured on a Jasco DIP-1000 digital polarimeter. IR spectra were recorded on a Jasco FT-5300 infrared spectrophotometer. EIMS was obtained with a VG Quattro GC/MS spectrometer. HRMS spectra were recorded on a Finnigan MAT-95XL mass spectrometer. The NMR spectra were recorded on a Bruker AVANCE DPX300 FT-NMR at $300 \mathrm{MHz}$ for ${ }^{1} \mathrm{H}$ and $75 \mathrm{MHz}$ for ${ }^{13} \mathrm{C}$ or on a Varian Unity INOVA 500 FT-NMR at $500 \mathrm{MHz}$ for ${ }^{1} \mathrm{H}$ and $125 \mathrm{MHz}$ for ${ }^{13} \mathrm{C}$, respectively, in $\mathrm{CDCl}_{3}$ using TMS as internal standard. Si gel (Merck, 230400 mesh) was used for column chromatography. Precoated Si gel plates (Merck, Kieselgel 60 F-254, $0.2 \mathrm{~mm}$ ) were used for analytical TLC.

Organism. The soft coral $S$. gibberosa, Alcyoniidea $(0.6 \mathrm{~kg}$, wet wt), was collected by hand via scuba at the coast of Kenting, in December 2000, at a depth of 10-15 m, and stored in a freezer until extraction. A voucher sample was deposited at the Department of Marine Resources, Sun Yat-Sen University (specimen no. NHSC 002).

Extraction and Isolation. The organism, S. gibberosa, was exhaustively extracted with EtOH. The EtOH extract was filtered and concentrated under reduced pressure, and the aqueous residue was successively partitioned with $n$-hexane and dichloromethane to afford the $n$-hexane $(4 \mathrm{~g})$ and dichloromethane $(11 \mathrm{~g})$ fractions, respectively. ${ }^{6}$ The dichloromethane fraction was chromatographed on Si gel 60 using MPLC, and elution was carried out by EtOAc- $n$-hexane (stepwise, 0:10, $1: 9, \ldots, 9: 1,10: 0$ ) then by $\mathrm{MeOH}-\mathrm{EtOAc}$ (stepwise, 0:10, 1:9, $\ldots, 9: 1,10: 0)$ to yield 55 fractions. Fraction 25 eluted with EtOAc $-n$-hexane $(2: 8)$ was further purified by normal-phase HPLC using acetone $-n$-hexane (gradient, 1:9 to 2:8) to yield $1(11 \mathrm{mg})$. Fraction 30 eluted with $n$-hexane-EtOAc (2:8) was separated by MPLC on Si gel 60 and $\mathrm{MeOH}$-dichloromethane (gradient, 0:100 to 1:99) to afford 2 (25 mg). Fractions 43 and 44 eluted with EtOAc $-n$-hexane (4:6) were purified separately by normal-phase HPLC using $\mathrm{MeOH}$-dichloromethane (gradi- 
ent, $1: 99$ to $5: 95)$ to yield $4(8.5 \mathrm{mg})$ and $\mathbf{3}(7.0 \mathrm{mg})$, respectively.

Gibberodione (1): colorless oil, $[\alpha]^{25} \mathrm{D}+20.8^{\circ}$ (c 0.72 , $\mathrm{CHCl}_{3}$ ); IR (neat) $v_{\max } 3020,2975,2932,2872,1715,1603$, $1453,1379,1217,1096 \mathrm{~cm}^{-1} ;{ }^{1} \mathrm{H}$ NMR $\left(\mathrm{C}_{5} \mathrm{D}_{5} \mathrm{~N}, 300 \mathrm{MHz}\right)$ and ${ }^{13} \mathrm{C}$ NMR $\left(\mathrm{C}_{5} \mathrm{D}_{5} \mathrm{~N}, 75 \mathrm{MHz}\right)$, see Table $1 ;{ }^{1} \mathrm{H}$ NMR $\left(\mathrm{CDCl}_{3}, 300\right.$ MHz) $\delta 5.89(1 \mathrm{H}, \mathrm{br}$ s, H-6), 2.83 (1H, ddd, $J=10.6,5.4,4.5$ $\mathrm{Hz}, \mathrm{H}-1), 2.54(1 \mathrm{H}$, dd, $J=10.8,9.0 \mathrm{~Hz}, \mathrm{H}-3), 2.46(1 \mathrm{H}, \mathrm{m}$, H-3), 2.33-2.41 (2H, m, H-2, H-8), 2.31 (1H, m, H-11), 2.15 (1H, m, H-8), $2.11\left(3 \mathrm{H}, \mathrm{s}, \mathrm{H}_{3}-15\right), 2.10(2 \mathrm{H}, \mathrm{m}, \mathrm{H}-9, \mathrm{H}-10), 1.61$ $(1 \mathrm{H}, \mathrm{m}, \mathrm{H}-2), 1.08(1 \mathrm{H}, \mathrm{m}, \mathrm{H}-9), 1.06\left(6 \mathrm{H}, \mathrm{d}, J=6.9 \mathrm{~Hz}, \mathrm{H}_{3}-\right.$ $\left.12, \mathrm{H}_{3}-13\right), 0.79\left(3 \mathrm{H}, \mathrm{d}, J=6.9 \mathrm{~Hz}, \mathrm{H}_{3}-14\right) ;{ }^{13} \mathrm{C} \mathrm{NMR}\left(\mathrm{CDCl}_{3}\right.$, $75 \mathrm{MHz}) \delta 206.0$ (C-4), 203.4 (C-5), 170.2 (C-7), 128.0 (C-6); 52.8 (C-1), 42.0 (C-3), 38.0 (C-11), 36.3 (C-9), 33.6 (C-10), 29.9 (C-15), 29.9 (C-8), 22.3 (C-2), 20.9 (C-13), 20.6 (C-12), 16.2 (C14); EIMS m/z $236\left(2.0,[\mathrm{M}]^{+}\right), 193$ (4.0), 179 (10.5), 165 (9.1), 151 (8.5), 135 (8.8), 123 (30.6), 109 (16.0), 107 (27.5), 95 (47.5), 81 (25.5), 71 (10.5), 67 (36.5); HREIMS $\mathrm{m} / \mathrm{z} 236.1781$ (calcd for $\left.\mathrm{C}_{15} \mathrm{H}_{24} \mathrm{O}_{2}, 236.1777\right)$.

Peroxygibberol (2): colorless oil, $[\alpha]^{25} \mathrm{D}+22.4^{\circ}$ (c 1.25, $\mathrm{CHCl}_{3}$ ); IR (neat) $v_{\max } 3598,3013,2967,2934,2878,1632$, 1456, 1379, 1294, 1232, 1190, 1105, $1001 \mathrm{~cm}^{-1}$; ${ }^{1} \mathrm{H}$ NMR $\left(\mathrm{CDCl}_{3}, 300 \mathrm{MHz}\right)$ and ${ }^{13} \mathrm{C} \mathrm{NMR}\left(\mathrm{CDCl}_{3}, 75 \mathrm{MHz}\right)$, see Table 2; EIMS $m / z 252\left(0.2,[\mathrm{M}]^{+}\right), 220\left(93.3,\left[\mathrm{M}-\mathrm{O}_{2}\right]^{+}\right), 205(58.4)$, $202\left(18.2,\left[\mathrm{M}-\mathrm{O}_{2}-\mathrm{H}_{2} \mathrm{O}\right]^{+}\right), 187$ (16.9), 177 (40.4), 162 (37.7), 149 (42.0), 125 (25.9); HRESIMS $\mathrm{m} / \mathrm{z} 275.1621$ (calcd for $\left.\mathrm{C}_{15} \mathrm{H}_{24} \mathrm{O}_{3}+\mathrm{Na}, 275.1623\right)$.

Sinugibberodiol (3): colorless oil, $[\alpha]^{25}{ }_{\mathrm{D}}-5.0^{\circ}$ (c 0.20 , $\mathrm{CHCl}_{3}$ ); IR (neat) $v_{\max } 3397,2970,2930,2870,1711,1644$, $1445,1382,1024 \mathrm{~cm}^{-1} ;{ }^{1} \mathrm{H}$ NMR $\left(\mathrm{CDCl}_{3}, 300 \mathrm{MHz}\right)$ and ${ }^{13} \mathrm{C}$ NMR $\left(\mathrm{CDCl}_{3}, 75 \mathrm{MHz}\right)$, see Table 3; FABMS $m / z 259$ (3.0, [M $\left.+\mathrm{Na}]^{+}\right), 237\left(2.7,[\mathrm{M}+\mathrm{H}]^{+}\right), 219\left(7.9,\left[\mathrm{M}-\mathrm{H}_{2} \mathrm{O}+\mathrm{H}\right]^{+}\right), 201$ (12.1, $\left.\left[\mathrm{M}-2 \mathrm{H}_{2} \mathrm{O}+\mathrm{H}\right]^{+}\right), 154$ (55.3), 137 (58.5), 136 (65.0), 117 (39.6); HRFABMS $\mathrm{m} / z 237.1853$ (calcd for $\mathrm{C}_{15} \mathrm{H}_{25} \mathrm{O}_{2}$, 237.1855)

Acetylation of 3. A solution of sinugibberodiol (3) $(2.4 \mathrm{mg}$, $0.009 \mathrm{mM})$ in pyridine $(0.2 \mathrm{~mL})$ was mixed with $\mathrm{Ac}_{2} \mathrm{O}(0.2 \mathrm{~mL})$, and the mixture was stirred at RT for $24 \mathrm{~h}$. After evaporation of excess reagent, the residue was purified by normal-phase HPLC to give the diacetyl derivative $\mathbf{3 a}$ (acetone $-n$-hexane, $1: 4,2.8 \mathrm{mg}, 0.009 \mathrm{mmol}, 87.5 \%$ ).

Sinugibberodiol diacetate (3a): colorless oil, $[\alpha]^{25} \mathrm{D}-31.3^{\circ}$ (c $0.8, \mathrm{CHCl}_{3}$ ), $-36.3^{\circ}$ ( $\left.c 0.8, \mathrm{MeOH}\right)$; IR (neat) $v_{\max } 2968,2928$, $2857,1738,1643,1445,1372,1238,1018 \mathrm{~cm}^{-1} ;{ }^{1} \mathrm{H}$ NMR $\left(\mathrm{CDCl}_{3}, 500 \mathrm{MHz}\right)$ and ${ }^{13} \mathrm{C} \mathrm{NMR}\left(\mathrm{CDCl}_{3}, 125 \mathrm{MHz}\right)$, see Table 3; EIMS $m / z 320\left(0.1,[\mathrm{M}]^{+}\right), 200\left(8.8,[\mathrm{M}-2 \mathrm{AcOH}]^{+}\right), 185$ (37.8), 171 (28.1), 159 (100.0), 143 (56.3), 131 (79.3), 117 (56.3).

Compound 4: colorless oil, $[\alpha]^{25}{ }_{\mathrm{D}}-52.5^{\circ}\left(\mathrm{c} 0.80, \mathrm{CHCl}_{3}\right)$; IR (neat) $v_{\max } 3360,2961,2913,2868,1640,1603,1460,1379$, $1215,1010 \mathrm{~cm}^{-1} ;{ }^{1} \mathrm{H} \mathrm{NMR}\left(\mathrm{CDCl}_{3}, 500 \mathrm{MHz}\right) \delta 5.15(1 \mathrm{H}, \mathrm{br} \mathrm{t}$, $J=7.5 \mathrm{~Hz}, \mathrm{H}-11), 5.00(1 \mathrm{H}, \mathrm{d}, J=10.0 \mathrm{~Hz}, \mathrm{H}-2), 4.85(1 \mathrm{H}, \mathrm{s}$, $\mathrm{H}-19), 4.78$ (1H, s, H-19), 4.63 (1H, dd, $J=10.5,3.0 \mathrm{~Hz}, \mathrm{H}-14)$, $2.52(1 \mathrm{H}$, septet, $J=7.0 \mathrm{~Hz}, \mathrm{H}-3), 2.48(1 \mathrm{H}, \mathrm{t}, J=10.0 \mathrm{~Hz}$, $\mathrm{H}-3$ ), 2.40 (1H, dd, $J=12.0,9.0 \mathrm{~Hz}, \mathrm{H}-7), 2.26$ (1H, m, H-10 $\alpha$ ), $2.18(1 \mathrm{H}, \mathrm{m}, \mathrm{H}-10 \beta), 2.19(2 \mathrm{H}, \mathrm{m}, \mathrm{H}-5 \alpha, \mathrm{H}-13 \alpha), 2.10(1 \mathrm{H}, \mathrm{dd}$, $J=12.0,10.5 \mathrm{~Hz}, \mathrm{H}-13 \beta), 1.76(1 \mathrm{H}, \mathrm{dd}, J=16.0,12.0 \mathrm{~Hz}$, $\mathrm{H}-5 \beta), 1.73(1 \mathrm{H}, \mathrm{m}, \mathrm{H}-6 \alpha), 1.73-1.69\left(2 \mathrm{H}, \mathrm{m}, \mathrm{H}_{2}-9\right), 1.68(3 \mathrm{H}$, $\left.\mathrm{s}, \mathrm{H}_{3}-20\right), 1.63(1 \mathrm{H}, \mathrm{dd}, J=17.0,9.0 \mathrm{~Hz}, \mathrm{H}-6 \beta), 1.13(3 \mathrm{H}, \mathrm{d}, J$ $\left.=7.0, \mathrm{H}_{3}-17\right), 1.11\left(3 \mathrm{H}, \mathrm{s}, \mathrm{H}_{3}-18\right), 1.07\left(3 \mathrm{H}, \mathrm{d}, J=7.0, \mathrm{H}_{3}-16\right)$;
${ }^{13} \mathrm{C}$ NMR $\left(\mathrm{CDCl}_{3}, 125 \mathrm{MHz}\right) \delta 149.3$ (C, C-8), 148.6 (C, C-1), 130.9 (C, C-12), 126.5 (CH, C-11), $125.3(\mathrm{CH}, \mathrm{C}-2), 111.5\left(\mathrm{CH}_{2}\right.$, C-19), $81.3(\mathrm{C}, \mathrm{C}-4), 71.3(\mathrm{CH}, \mathrm{C}-14), 54.8(\mathrm{CH}, \mathrm{C}-7), 50.1(\mathrm{CH}$, C-3), $44.3\left(\mathrm{CH}_{2}, \mathrm{C}-13\right), 40.2\left(\mathrm{CH}_{2}, \mathrm{C}-9\right), 27.9\left(\mathrm{CH}_{2}, \mathrm{C}-5\right), 27.3$ $\left(\mathrm{CH}_{2}, \mathrm{C}-10\right), 26.6(\mathrm{CH}, \mathrm{C}-15), 26.5\left(\mathrm{CH}_{3}, \mathrm{C}-17\right), 25.5\left(\mathrm{CH}_{2}, \mathrm{C}-6\right)$, $24.7\left(\mathrm{CH}_{3}, \mathrm{C}-16\right), 23.5\left(\mathrm{CH}_{3}, \mathrm{C}-18\right), 18.0\left(\mathrm{CH}_{3}, \mathrm{C}-20\right)$; EIMS $\mathrm{m} / z$ $304\left(1.1,[\mathrm{M}]^{+}\right), 286\left(0.9,\left[\mathrm{M}-\mathrm{H}_{2} \mathrm{O}\right]^{+}\right), 268\left(0.5,\left[\mathrm{M}-2 \mathrm{H}_{2} \mathrm{O}\right]^{+}\right)$, 261 (1.5), 243 (2.1), 203 (3.0), 193 (4.3), 175 (4.0), 161 (4.3), 135 (11.3). ${ }^{1} \mathrm{H}$ and ${ }^{13} \mathrm{C}$ NMR spectroscopic data were found to be in full agreement with those reported previously for sarcophytol L (4). ${ }^{17}$

Cytotoxicity Testing. Cell lines were purchased from the American Type Culture Collection (ATCC). Cytotoxicity assays of the test compounds $\mathbf{1}, \mathbf{2}$, and $\mathbf{4}$ were performed using the MTT [3-(4,5-dimethylthiazole-2-yl)-2,5-diphenyltetrazolium bromide] colorimetric method. ${ }^{18,19}$

Acknowledgment. This work was supported by a grant from the National Science Council of the Republic of China (Contract No. NSC-92-2323-B-110-002) awarded to J.-H.S.

Note Added after ASAP Publication: The NOE interaction between $\mathrm{H}-8(\alpha)$ and the methyl at $\mathrm{C}-11$ in Figure 3 was omitted in the version published on the Web on July 20, 2005. The corrected figure appears in the version posted on July 25, 2005.

\section{References and Notes}

(1) Ahmed, A. F.; Su, J.-H.; Shiue, R.-T.; Pan, X.-J.; Dai, C.-F.; Kuo, Y.H.; Sheu, J.-H. J. Nat. Prod. 2004, 67, 592-597.

(2) Sheu, J.-H.; Ahmed, A. F.; Shiue, R.-T.; Dai, C.-F.; Kuo, Y.-H. J. Nat. Prod. 2002, 65, 1904-1908, and references therein.

(3) Sung, P.-J.; Su, J.-H.; Duh, C.-Y.; Chiang, M. Y.; Sheu, J.-H. J. Nat Prod. 2001, 64, 318-323.

(4) Sheu, J.-H.; Chen S.-P.; Sung, P.-J.; Chiang, M. Y.; Dai, C.-F Tetrahedron Lett. 2000, 41, 7885-7888.

(5) Sheu, J.-H.; Sung, P.-J.; Su, J.-H.; Duh, C.-Y.; Chiang, M. Y. Tetrahedron 1999, 55, 14555-14564.

(6) Ahmed, A. F.; Dai, C.-F.; Kuo, Y.-H.; Sheu, J.-H. Steroids 2003, 68, $377-381$.

(7) Cullmann, F.; Becker, H. Phytochemistry 1998, 47, 237-245.

(8) Endo, M.; Nakagawa, M.; Hamamoto, Y.; Nakanishi, T. J. Chem. Soc. Chem. Commun. 1983, 322-323 and 980.

(9) Hiroya, K.; Zhang, H.; Ogasawara, K. Synlett. 1999, 5, 529-532.

(10) Tamura, R.; Watabe, K.-i.; Ono, N.; Yamamoto, Y. J. Org. Chem. 1993 $58,4471-4472$.

(11) Jakupovic, J.; Schuster, A.; Bohlmann, F.; Dillon, M. O. Phytochemistry 1988, 27, 1771-1775.

(12) Hirota, H.; Okino, T.; Yoshimura, E.; Fusetani, N. Tetrahedron 1998 54, 13971-13980.

(13) Wang, G.-H.; Ahmed, A. F.; Kuo, Y.-H.; Sheu, J.-H. J. Nat. Prod. 2002 , $65,1033-1036$

(14) Vieira, L. M.; Kijjoa, A.; Pereira, J. A.; Gedris, T. E.; Herz, W. Phytochemistry 1997, 45, 111-115.

(15) Hu, L.; Chen, Z. Phytochemistry 1997, 44, 1287-1290.

(16) Triana, J.; López, M.; Rico, M.; González-Platas, J.; Quintana, J.; Estévez, F.; León, F.; Bermejo, J. J. Nat. Prod. 2003, 66, 943-948.

(17) Osabe, K.; Kobayashi, M. Chem. Pharm. Bull. 1989, 37, 1192-1196.

(18) Alley, M. C.; Scudiero, D. A.; Monks, A.; Hursey, M. L.; Czerwinski, M. J.; Fine, D. L.; Abbott, B. J.; Mayo, J. G.; Shoemaker, R. H.; Boyd M. R. Cancer Res. 1988, 48, 589-601.

(19) Scudiero, D. A.; Shoemaker, R. H.; Paull, K. D.; Monks, A.; Tierney, S.; Nofziger, T. H.; Currens, M. J.; Seniff, D.; Boyd, M. R. Cancer Res. 1988, 48, 4827-4833.

NP050114U 